\title{
A PROPósITO DE AMERIGO VESPUCCI
}

\author{
Recebemós do nosso colaborador, o Prof. Thomaz Oscar Mar- \\ condes de Souza, a carta abaixo transcrita, que, como sempre o fi- \\ zemos, estampamos com prazer.
}

S. Paulo, 15 de março de 1953

Sr. Frofessor Dr. E. Simões de Paula

Diretor da "Revista de História".

Capital.

No número 11 da "Revista de História" correspondente aos meses de julho a setembro do ano próximo findo, nas páginas 189 a 194 , vem publicada uma crítica do professor dr. Giuseppe Caraci da Universidade de Roma, sôbre um artigo que o sr. dr. Virgúlio Corrêa Filho estampou na "Revista Brasileira de Geografia", ano XII, páginas 94 e 95, sob o título "Vultos da Geografia do Brasil", ocupando-se de Vespucci.

Nessa crítica o professor dr. Caraci aponta vários equívocos do sr. dr. Virgílio Corrêa Filho, entre êles aquêle referente à data do nascimento do Florentino.

Acontece que agora, no número 13 da "Revista de História", correspondente aos meses de janeiro a março do ano em curso, o sr. dr. Virgílio Corrêa Filho respondendo à referida crítica do professor dr. Caraci, diz com elogiosas palavras à nossa pessoa, o que penhorado agradecemos, que a data que indicou no seu trabalho como aquela do nascimento de Vespucci, êle a encon'rou às páginas 19 do nosso estudo publicado em 1949 sob o título "Amerigo Vespucci e suas viagens", o que é pura verdade.

Como historiador que somos, temos por sagrado princípio pôr a verdade acima de tudo e, assim sendo, confessamos que a data que figura no nosso citado livro como aquela do nascimento do famoso navegador e cosmógrafo florentino, está errada. Ó êro ocorreu porque ao ser feita a última revisão ficamos enfermo e, confiamos a revisão a uma pessoa que por um lamentável esquecimento, deixou de indicar a data certa do nascimento de Vespucci, que pessoa amiga, residente em Florença, nos tinha comunicado por carta aérea.

Não padece a menor dúvida, diante das mais recentes pesquisas, que Amerigo Vespucci, como afirma o professor dr. Caraci, nasceu em Florença no mês de março de 1454 , provàvelmente no dia 17 ou 18 dêsse mês, tendo sido batisado a 18 do referido mês e ano, na igreja S. João Batista de Florença.

Tratando-se de outros equívocos que o professor $\mathrm{dr}$. Caraci aponta no artigo publicado pelo sr. dr. Virgílio Corrêa Filho na "Revista Brasileira de Geografia" a respeito de Vespucci, deixamos de comentá-los porque êles não são encontrados no nosso citado trabalho, o que vem evidenciar que êste nosso ilustre e gentil conterrâneo recorreu a obras de outros historiadores, além da nossa, ao escrever a sua biografia sôbre o famoso Florentino.

Pela publicação desta, antecipadamente contessamos gratos e somos.

Crdos. Atos. Obgdos.

(a) THOMAZ OSCAR MARCONDES DE SOUZA 